\title{
Photodynamic Inactivation of Pseudomonas aeruginosa by PHEMA Films Loaded with Rose Bengal: Potentiation Effect of Potassium Iodide
}

\author{
Ana M. López-Fernández ${ }^{1}$, Ignacio Muñoz Resta ${ }^{1}\left(\mathbb{D}\right.$, Rosa de Llanos ${ }^{2, *}$ and Francisco Galindo ${ }^{1, *(D)}$ \\ 1 Departamento de Química Inorgánica y Orgánica, Universitat Jaume I, Av. V. Sos Baynat s/n, \\ 12071 Castellón, Spain; lopezan@uji.es (A.M.L.-F.); resta@uji.es (I.M.R.) \\ 2 Unidad Predepartamental de Medicina, Universitat Jaume I, Av. V. Sos Baynat s/n, 12071 Castellón, Spain \\ * Correspondence: dellanos@uji.es (R.d.L.); francisco.galindo@uji.es (F.G.)
}

check for updates

Citation: López-Fernández, A.M.; Muñoz Resta, I.; de Llanos, R.; Galindo, F. Photodynamic

Inactivation of Pseudomonas aeruginosa by PHEMA Films Loaded with Rose Bengal: Potentiation Effect of Potassium Iodide. Polymers 2021, 13, 2227. https://doi.org/10.3390/ polym13142227

Academic Editor: David Mecerreyes

Received: 10 June 2021

Accepted: 3 July 2021

Published: 6 July 2021

Publisher's Note: MDPI stays neutral with regard to jurisdictional claims in published maps and institutional affiliations.

Copyright: (C) 2021 by the authors Licensee MDPI, Basel, Switzerland. This article is an open access article distributed under the terms and conditions of the Creative Commons Attribution (CC BY) license (https:// creativecommons.org/licenses/by/ $4.0 /)$

\begin{abstract}
Four formulations have been used to produce different poly(2-hydroxyethyl methacrylate) (PHEMA) thin films, containing singlet oxygen photosensitizer Rose Bengal (RB). The polymers have been characterized employing Thermogravimetric Analysis (TGA), Attenuated Total Reflectance Fourier Transform Infrared Spectroscopy (ATR-FTIR) and UV-vis Absorption Spectroscopy. When irradiated with white light $(400-700 \mathrm{~nm})$ films generated singlet oxygen $\left({ }^{1} \mathrm{O}_{2}\right)$, as demonstrated by the reactivity with ${ }^{1} \mathrm{O}_{2}$ trap 9,10-dimethylanthracene (DMA). Material with the highest RB loading (polymer A4, $835 \mathrm{nmol} \mathbf{R B} / \mathrm{g}$ polymer) was able to perform up to ten cycles of DMA oxygenation reactions at high conversion rates (ca. 90\%). Polymer A4 was also able to produce the complete eradication of a Pseudomonas aeruginosa planktonic suspension of $8 \log _{10} \mathrm{CFU} / \mathrm{mL}$, when irradiated with white light (total dose $72 \mathrm{~J} / \mathrm{cm}^{2}$ ). The antimicrobial photodynamic effect was remarkably enhanced by adding potassium iodide $(100 \mathrm{mM})$. In such conditions the complete bacterial reduction occurred with a total light dose of $24 \mathrm{~J} / \mathrm{cm}^{2}$. Triiodide anion $\left(\mathrm{I}_{3}{ }^{-}\right)$generation was confirmed by UVvis absorption spectroscopy. This species was detected inside the PHEMA films after irradiation and at concentrations ca. $1 \mathrm{M}$. The generation of this species and its retention in the matrix imparts longlasting bactericidal effects to the RB@PHEMA polymeric hydrogels. The polymers here described could find potential applications in the medical context, when optimized for their use in everyday objects, helping to prevent bacterial contagion by contact with surfaces.
\end{abstract}

Keywords: PHEMA; Rose Bengal; photodynamic inactivation; antimicrobial materials; bactericidal materials; Pseudomonas aeruginosa; singlet oxygen; photosensitizers; light

\section{Introduction}

Infections by microorganisms cause the death of 13 million people worldwide annually [1], and the situation is worsening due to the emergence of antibiotic-resistant strains [2]. In hospital settings, the occurrence of nosocomial infections has become a public health problem, involving an economic burden of $\$ 33$ billion each year in the United States [3]. Specifically, Pseudomonas aeruginosa is responsible for 10-15\% of such hospitalacquired infections and is associated with high mortality rates (18-61\%) [4]. Hence, it is not surprising that materials with antimicrobial properties are highly demanded by society. The majority of antimicrobial materials are designed using polymers containing groups with well-known microbiocidal properties, like ammonium and phosphonium cations [5-13]. In addition to its application in health, surface contamination is also an issue for the food industry and hence, solutions are actively sought in the Materials Science area [14]. An alternative strategy that is receiving increasing attention is the use of visible light to activate materials via the encapsulation of a photosensitizer capable of converting the absorbed energy into cytotoxic species. Historically, the development of this scientific discipline started with studies on photosensitization in solution, this approach 
being termed as antimicrobial photodynamic inactivation (aPDI), among other denominations $[15,16]$. In aPDI the combination of light and photoactive molecules gives rise to reactive oxygen species (ROS). To summarizing, the mechanism of photosensitization implies the absorption of light by a molecule that is activated to an excited state. From that state, electron or energy transfer can take place (type I and II mechanisms, respectively) to the surrounding ground state oxygen. This process leads to the formation of radical species (hydroxyl radical, superoxide anion, via type I mechanism) and/or singlet oxygen $\left({ }^{1} \mathrm{O}_{2}\right.$, via type II mechanism), which induce the killing of pathogenic microorganisms. The above process has often been described to occur for photosensitizers in solution [17-23], and also when the photosensitizers are immobilized on a polymeric matrix [24-27]. Polymeric matrix recently used in aPDI include, among others, polystyrene nanofibers [28], polylactic acid [29], polyolefin thermoplastic elastomers [30], pyridinium modified Merrifield resins [31], polyether block amide [32], chitosan [33], wool keratine [34], cellulose [35], nylon [36] and polyacrylonitrile [36].

One of the most popular polymers used in Biomedicine is poly(2-hydroxyethyl methacrylate) (PHEMA). Due to its excellent biocompatibility, PHEMA has been used for the manufacture of contact lenses [37], ureteral stents [38] and platforms for neural growth [39]. But the applications of PHEMA materials go beyond the medical field and PHEMA can be used in the development of oxygen sensing materials [40], ion-selective membranes [41], batteries [42], and polymers for environmental remediation [43]. Due to the transparency of such materials, the encapsulation of optically active systems is especially attractive. Since 2005 we have designed and synthesized tailored coloured or emissive PHEMA hydrogels for various sensing applications [44-50], and more recently we have encapsulated a photoactive hexanuclear molybdenum complex in a PHEMA matrix. It has been found to be active against Staphylococcus aureus after irradiation with visible light [51]. As a continuation of such work, we are now reporting the encapsulation of the photosensitizer Rose Bengal (RB) into a matrix of cross-linked cationic PHEMA (RB@PHEMA) displaying photo-antibacterial properties against Gram-negative bacteria $P$. aeruginosa in planktonic suspension. The PHEMA-related materials described above use swelling [52] and covalent binding [53] as strategies to incorporate photosensitizers. On the contrary, the strategy used here consisted of the dissolution of underivatized RB in the polymerizable formulation of monomers and crosslinker.

In the aPDI context, it has been described that iodide anion $\left(\mathrm{I}^{-}\right)$can boost the photodynamic killing of bacterial and fungal species [54-64]. This is especially appealing for anionic photosensitizers, like RB, which are particularly inefficient against Gram-negative bacteria in solution [57]. However, in combination with $\mathrm{I}^{-}$the antimicrobial photodynamic action is enhanced several orders of magnitude.

In the present study, the photo-antimicrobial properties of RB@PHEMA films have been demonstrated against $P$. aeruginosa. In addition, this is the first time that a photoactive PHEMA material is used in combination with potassium iodide, which has remarkably enhanced its bactericidal activity.

\section{Materials and Methods}

\subsection{Materials}

Rose Bengal disodium salt (RB, $\geq 85 \%$, Sigma, St. Louis, MO, USA), 2-hydroxyethyl methacrylate (HEMA) (97\%, Acros Organics, Waltham, MA, USA), (3-acrylamidopropyl) trimethyl-ammonium chloride solution (ATAC) $\left(75 \mathrm{wt} . \%\right.$ in $\mathrm{H}_{2} \mathrm{O}$, Aldrich Chemistry, St. Louis, MO, USA), poly(ethylene glycol) dimethacrylate average Mn 550 (PEGDMA) (Aldrich Chemistry, St. Louis, MO, USA), $\alpha, \alpha$-azoisobutyronitrile (AIBN) ( $\geq 95 \%$, Glentham, Corsham, UK), 9,10-dimethylanthracene (DMA) (97\%, Alfa Aesar, Waltham, MA, USA), potassium iodide (analytical grade, Scharlau, Barcelona, Spain) were used as received. The solvents were spectroscopic grade (Scharlab, Barcelona, Spain). 


\subsection{Hydrogel Synthesis}

The polymeric hydrogels were synthesized according to the following procedure [51]: Rose Bengal disodium salt (from 0.005 to $0.1 \%$ wt., relative to the total mass of monomers and crosslinker) was dissolved in a mixture of HEMA:ATAC:PEGDMA (85:5:10 wt.\%, respectively). Then, AIBN was added and dissolved (1 wt. \% relative to the total mass of monomers and crosslinker). A small part of this solution was pipetted into the narrow space formed between two microscope glass slides separated by two thin coverslips at the edges. The system was placed in an oven at $85^{\circ} \mathrm{C}$ for $15 \mathrm{~min}$. After polymerization, the two glass slides were separated and the film was removed and washed with distilled water to eliminate any unreacted material. To facilitate the unmoulding process, the glass slides were previously treated with silicone oil and put in an oven at $200{ }^{\circ} \mathrm{C}$ for $60 \mathrm{~min}$. The films were typically $75 \times 25 \mathrm{~mm}^{2}$ and could be cut into pieces to obtain samples with the desired weight.

\subsection{Characterization}

The samples were analysed by Attenuated Total Reflectance Fourier Transform Infrared Spectroscopy (ATR-FTIR) (Jasco, Tokyo, Japan) with a Jasco FT/IR 6200 type A with a TGS detector. The spectra were recorded in the range $4000-400 \mathrm{~cm}^{-1}$, with 128 scans per spectrum and a resolution of $4 \mathrm{~cm}^{-1}$. Thermogravimetric analyses (TGA) (Mettler Toledo, Columbus, OH, USA) were performed with a TG-STDA Mettler Toledo model TGA/SDTA851e/LF/1600 from $25^{\circ} \mathrm{C}$ to $500{ }^{\circ} \mathrm{C}$, at a heating rate of $10{ }^{\circ} \mathrm{C} / \mathrm{min}$ under air atmosphere. All measurements were done in $40 \mu \mathrm{L}$ platinum crucibles and an empty platinum crucible was used as a reference. Sample masses of ca. $10 \mathrm{mg}$ were used. The thickness of the films was measured with a Mitutoyo Digimac Caliper (500 series) (Mitutoyo Ltd, Andover, UK). UV-vis spectra were recorded on a Cary 60 UV-vis spectrophotometer Agilent Technologies, Santa Clara, CA, USA). The films were maintained between two microscope slides during the absorption measurements.

\subsection{Photochemical Studies}

Photooxygenation reactions were performed inside $10 \mathrm{~mL}$ vials containing $50 \mathrm{mg}$ of the polymeric film and $3 \mathrm{~mL}$ of the ${ }^{1} \mathrm{O}_{2}$ trap DMA $\left(10^{-4} \mathrm{M}\right.$ in EtOH:H$: \mathrm{H}_{2} \mathrm{O}, 1: 1$, v:v). Irradiations were carried out using two white light LED lamps ( $9 \mathrm{~W}$ each, ca. $400-700 \mathrm{~nm}$ emission output; see Figure S1 in the Electronic Supporting Information) placed $2.5 \mathrm{~cm}$ away from the vial under continuous stirring (light irradiance $180 \mathrm{~mW} / \mathrm{cm}^{2}$ for each lamp at $2.5 \mathrm{~cm}$ ). The evolution of the photoreactions was monitored over time by means of UV-vis absorption spectrophotometry (decrease of absorbance at $377 \mathrm{~nm}$ ). The kinetic traces were fitted to the following pseudo-first order model [51]: $\ln \left(\mathrm{A} / \mathrm{A}_{0}\right)=-\mathrm{k}_{\mathrm{obs}} \cdot \mathrm{t}$, where $A_{0}$ is the initial absorbance of DMA, $A$ is the absorbance of DMA at time $t$, and $k_{o b s}$ is the observed kinetic constant.

\subsection{Microorganisms and Growth Conditions}

The Gram (-) bacterial strain P. aeruginosa ATCC 27.853 was acquired from the American Type Culture Collection (ATCC, Rockville, MD, USA). Microorganisms were routinely seeded on Mueller Hilton Agar (MHA) (Scharlau, Spain) and cultured aerobically overnight at $35^{\circ} \mathrm{C}$.

\subsection{Antimicrobial Photodynamic Inactivation Experiments}

The aPDI experiments were carried out by exposing a sample of bacteria in planktonic state (see below for details) to $25 \mathrm{mg}$ films loaded with/without RB and with/without 100 $\mathrm{mM}$ KI solution. The following samples and controls were performed: cells without KI (A, control); cells with $\mathrm{KI}$ (B, control); cells without $\mathrm{KI}$ and incubated with RB-films (C, sample); cells without $\mathrm{KI}$ and incubated with no RB-films (D, control); cells with $\mathrm{KI}$ and incubated with RB-films (E, sample); cells with KI and incubated with no RB-films (F, control). These six groups were subjected to irradiation (named with uppercase letters, A-F) and in parallel, 
the same groups were kept in darkness as controls (named with lowercase letters, a-f). Irradiations were carried out with a source of white light LED TENKO ECO $50 \mathrm{~W}$ (output $400-700 \mathrm{~nm}$, light irradiance $80 \mathrm{~mW} / \mathrm{cm}^{2}$ at a distance of $2.5 \mathrm{~cm}$; see Figure S2 in the Electronic Supporting Information). Previously to the aPDI experiments, films loaded with/without RB were first sterilized by dipping them in $70 \%$ ethanol and subsequently air-dried.

The bacterial inoculum was prepared in sterilised distilled water and adjusted to $1.00 \pm 0.03$ on the McFarland scale (microbial suspensions containing $>3 \times 10^{8}$ bacteria $/ \mathrm{mL}$ ). An aliquot of $1 \mathrm{~mL}$ of the bacterial suspension was equally distributed to a 12-well plate, and then, either $1 \mathrm{~mL}$ of sterilized distilled water or $1 \mathrm{~mL}$ of $200 \mathrm{mM} \mathrm{KI}$ stock solution was also transferred to the plate to achieve a final microbial suspension of $\approx 10^{8}$ bacteria $/ \mathrm{mL}$ and a final $100 \mathrm{mM} \mathrm{KI}$ concentration. Irradiation of the 12-well plate containing samples and controls (A-F) were exposed to white light keeping $2.5 \mathrm{~cm}$ of distance between the lamp and the plates, at room temperature and under agitation in an orbital shaker (120 rpm). Aliquots of $75 \mu \mathrm{L}$ of samples and controls were collected at different times of light exposure (5 min: $24 \mathrm{~J} / \mathrm{cm}^{2} ; 10 \mathrm{~min}: 48 \mathrm{~J} / \mathrm{cm}^{2} ; 15 \mathrm{~min}: 72 \mathrm{~J} / \mathrm{cm}^{2}$ and $30 \mathrm{~min}: 144 \mathrm{~J} / \mathrm{cm}^{2}$ ). For the darkness condition, the 12-well plate containing samples and controls (a-f) were kept in the dark for $30 \mathrm{~min}$ at room temperature and under agitation in an orbital shaker $(120 \mathrm{rpm})$. Aliquots of $75 \mu \mathrm{L}$ of samples and controls were collected at $30 \mathrm{~min}$.

After completing the aPDI protocol (or dark incubation), relative cell survival was evaluated for each sample and control aliquots from both irradiated and dark conditions, by counting colony-forming units (CFU) on MHA. To do this, the initial suspensions (75 $\mu \mathrm{L}$ aliquots of samples and controls) were serially diluted 10 -fold in sterile distilled water to give concentrations of $10^{-1}$ to $10^{-5}$ times. Drops of $5 \mu \mathrm{L}$ of each dilution and the original suspension were spotted onto MHA plates (plate-serial dilution spotting) using a multichannel pipette, and were then incubated overnight at $35^{\circ} \mathrm{C}$. After $24 \mathrm{~h}$, at least one dilution level yielded 15-60 CFU was counted, and CFU/mL was calculated.

\subsection{Statistical Analysis}

All the experiments were performed in three or four independent replicates. Results are expressed as mean \pm standard deviation. Mean comparisons were performed after verifying homogeneity of variances using Barlett's test. In cases of homoscedasticity, differences among treatments were analysed by one-way analysis of variance (ANOVA) followed by Tukey's multiple comparison test. If heterogeneity of variances existed, robust tests were carried out as follows. Welch's test was used to check for differences among treatments, with Game-Howells's test used to establish differences among treatments. Comparisons of the means with $p$ values less or equal than 0.05 were regarded as significantly different in all tests. All statistical analysis was performed using the IBM SPSS Statistics, version 27 (SPSS Inc., Chicago, IL, USA).

\section{Results and Discussion}

\subsection{Preparation and Characterization of RB@PHEMA Films}

Synthesis of PHEMA films was carried out by thermally initiated radical polymerisation (AIBN as initiator) as previously reported [51]. The corresponding amount of RB disodium salt (from 0.005 to $0.1 \% \mathrm{wt}$.) and initiator (1\% wt.) was dissolved in a mixture of monomers 2-hydroxyethyl methacrylate (HEMA)/(3-acrylamidopropyl)trimethylammonium chloride solution (ATAC) and cross-linker poly(ethylene glycol) dimethacrylate (PEGDMA, average Mn 550). The indicated \% wt. of RB and AIBN are relative to the total amount of monomers and crosslinker. Formulas of HEMA, ATAC and PEGDMA can be seen in Figure 1. 


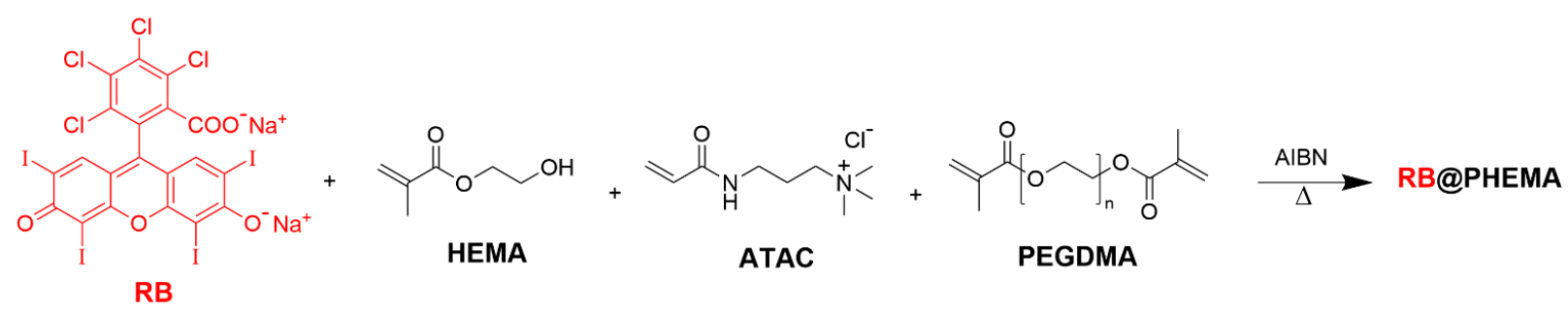

Figure 1. Structures of photosensitizer RB and monomers (HEMA, ATAC) and crosslinker (PEGDMA) used to synthesize RB@PHEMA.

The chosen internal proportion of the acrylic polymerizable molecules HEMA:ATAC: PEGDMA was 85:5:10 (in wt.\%). Such formulation was chosen considering our previous experience with encapsulation of optically active molecules [44-51]. In previous investigations, it was found that the appropriate choice of monomers and cross-linkers gave rise to materials with no detectable dye leaching outside the polymeric matrix, although this feature depends largely on the nature of the dye. For instance, a very hydrophobic sensing dye like 1,2-diaminoantraquinone remained trapped in the interior of PHEMA cross-linked films for months $[46,47,50]$. However, for anionic xanthenic dyes, the use of a cationic monomer is mandatory to create the appropriate electrostatic attraction as previously demonstrated for PHEMA entrapping the anionic sensor DAF-FM [49]. In this regard, ATAC monomer, with a permanent positive charge, was used for this purpose, since it allows the formation of an ion pair with the negatively charged $\mathbf{R B}$ (without the need of covalent attachment). Regarding the crosslinker, it was previously found that PEGDMA in a low proportion (10\%) was appropriate to produce films with good flexibility, strength, manipulability and the desired permeability to small chemical species in aqueous solutions. Polymerization was carried out inside a mould made with two glass slides and two coverslips, leading to thin films of up to $75 \times 25 \mathrm{~mm}^{2}$ (width of $180 \pm 10 \mu \mathrm{m}$ measured with a digital micrometre), which were easily cut into small pieces using scissors (leading to small rectangular pieces of $50 \mathrm{mg}$ or $25 \mathrm{mg}$ for irradiations). Pictures of representative examples of RB@PHEMA were taken to illustrate their transparency (Figure 2a) and flexibility (Figure 2b). An advantageous feature of the herein proposed encapsulation method in comparison to others previously reported, stems from the fact that no derivative of $\mathbf{R B}$ bearing a polymerizable group is required for the entrapment of photosensitizers in polymeric matrices [53]. Another difference of the followed approach is that the amount of entrapped RB can be precisely controlled just by dissolving the desired concentration of RB in the polymerizable mixture (see discussion below regarding UV-vis measurements of encapsulated RB). The alternative methodology implying dye loading by swelling of the matrix is also a frequently used strategy [52] but, in such cases, it is difficult to control the concentration of dye entrapped into the polymer. However, for the method described here, the final concentration of the photosensitizer inside the matrix is exactly the initial concentration before polymerization. As mentioned in the Introduction, we have successfully used this strategy for entrapping a variety of optically active molecules, from aromatic ketones $[46,47,50]$ and xanthenic dyes [49], to flavylium cations [44,45] and molybdenum clusters [51], all retaining their properties after the thermal polymer formation.

Several concentrations of RB were assayed to find the one yielding optimal photochemical activity. Thus, four films (A1-A4) were prepared with the above-mentioned formulation of HEMA, ATAC and PEGDMA but differing only in RB loading, ranging from $0.005 \% \mathrm{wt}$. to $0.1 \% \mathrm{wt}$. (or from 42 to $835 \mathrm{nmol} \mathrm{RB/g}$ polymer). An additional fifth film (B) was also prepared, without the photosensitizer, and used as a control. The concentration of $\mathbf{R B}$ in the films can be seen in Table 1.

The thermal properties of the films were determined by thermogravimetric analysis (TGA). As can be seen in Figure 3, for the thermograms and in Table 1 for the data, all the polymers under study displayed onset degradation temperatures $\left(T_{5 \%}\right)$ around $225^{\circ} \mathrm{C}$ and maximum degradation temperatures $\left(T_{\max }\right)$ around $356^{\circ} \mathrm{C}$. These values are comparable 
to similar PHEMA materials described in the literature, with differences attributable to variations in the monomer/cross-linker composition and the polymerization method. As illustrative references, D. Park et al. reported a polymer made with HEMA and ethylene glycol dimethacrylate (EGDMA) in a ratio of $95: 5$ displaying a $T_{5 \%}$ of ca. $253{ }^{\circ} \mathrm{C}$ and a $T_{\max }$ of ca. $350{ }^{\circ} \mathrm{C}$ [65]. More recently, Muñoz-Bonilla et al. reported an antimicrobial material made with HEMA and poly(ethylene glycol) diacrylate (EGDA) in a ratio of 5:1, which have a $T_{5 \%}$ of ca. $317^{\circ} \mathrm{C}$ and a $T_{\max }$ of ca. $388^{\circ} \mathrm{C}$ [66]. Polymer B, without RB, resulted slightly more stable than A1-A4, which have similar properties, irrespective of the photosensitizer concentration.

(a)

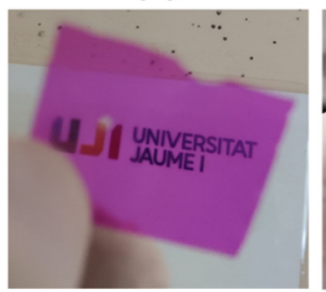

(b)

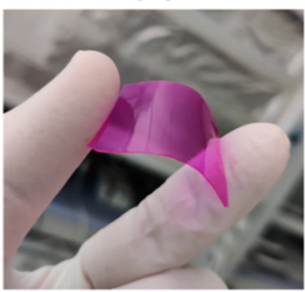

(c)

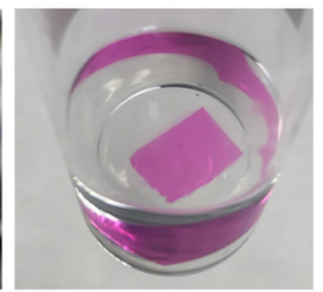

Figure 2. (a,b): pictures of a representative film of polymer A4 (size $\left.30 \times 25 \mathrm{~mm}^{2}\right)$ illustrating its transparency and flexibility; (c): picture of another film of polymer A4 (size $14 \times 10 \mathrm{~mm}^{2}$ ) immersed in water for four months, illustrating the absence of RB leaching.

Table 1. Thermal properties of films A1-A4 and B determined by TGA, and observed kinetic constant (average of three measurements) of the reaction of DMA with ${ }^{1} \mathrm{O}_{2}$ generated by irradiation of the films.

\begin{tabular}{cccccc}
\hline Polymer & $\begin{array}{c}\text { RB Loading } \\
\text { (nmol RB/g Polymer) }\end{array}$ & $\begin{array}{c}\boldsymbol{T}_{\mathbf{5} \%} \\
\left({ }^{\circ} \mathbf{C}\right)\end{array}$ & $\begin{array}{l}\boldsymbol{T}_{\mathbf{2 0} \%} \\
\left({ }^{\circ} \mathbf{C}\right)\end{array}$ & $\begin{array}{c}\boldsymbol{T}_{\max } \\
\left({ }^{\circ} \mathbf{C}\right)\end{array}$ & $\begin{array}{c}\mathbf{k}_{\text {obs }} \mathbf{1 0}^{\mathbf{3}} \\
\left(\mathbf{m i n}^{-1}\right)\end{array}$ \\
\hline A1 & 42 & 222.8 & 307.8 & 354.0 & $184 \pm 39^{\mathrm{a}, \mathrm{b}}$ \\
A2 & 83 & 227.9 & 311.9 & 352.9 & $221 \pm 41^{\mathrm{b}}$ \\
A3 & 417 & 228.5 & 311.9 & 354.5 & $223 \pm 48^{\mathrm{b}}$ \\
A4 & 835 & 225.9 & 311.4 & 359.7 & $270 \pm 30^{\mathrm{b}}$ \\
B & 0 & 219.8 & 312.4 & 366.8 & $56 \pm 13^{\mathrm{a}}$ \\
\hline
\end{tabular}

a,b: $k_{o b s}$ values sharing the same superscript letter are not significantly different from each other (one-way ANOVA, $p \leq 0.01)$.

(a)

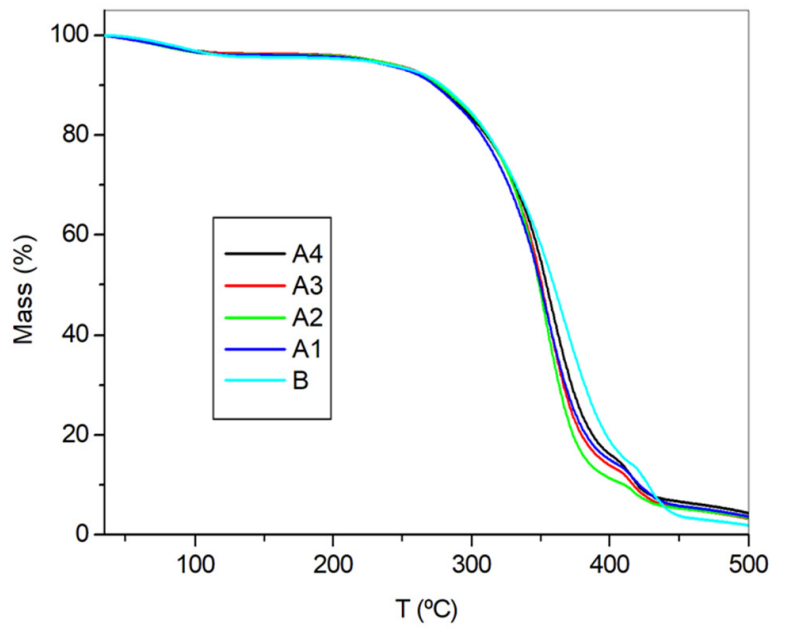

(b)

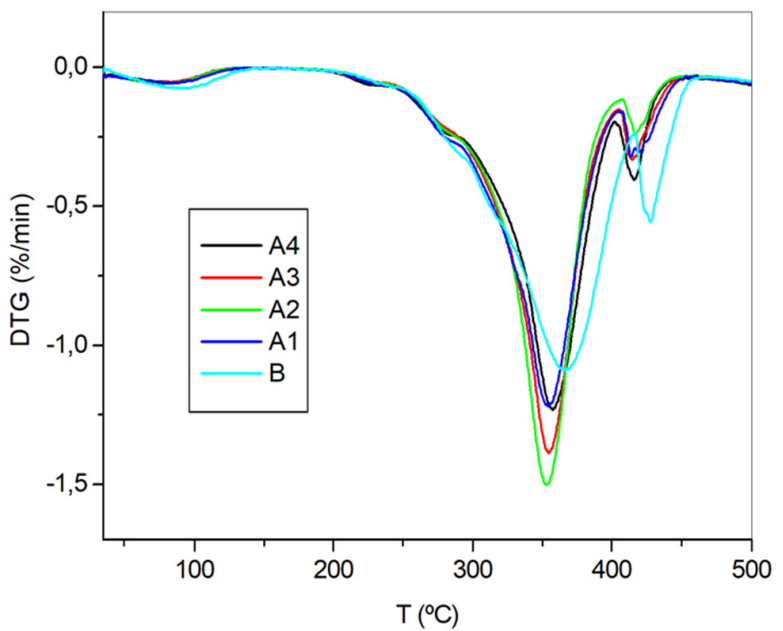

Figure 3. (a) Thermograms for films A1-A4, B and (b) the first derivative of such thermograms. 
Analysis of the materials by ATR-FTIR yielded a series of spectra with almost identical features, as expected, since the concentration of photosensitizer is too low to be detected by this technique (Figure 4). The main bands of the spectra were the corresponding to hydroxyl stretching (around 3700-3100 $\mathrm{cm}^{-1}$ ), carbonyl stretching (around $1712 \mathrm{~cm}^{-1}$ ) and characteristic vibrations of C-O bond in the range $1300-1000 \mathrm{~cm}^{-1}$. Similar features were described for other PHEMA materials reported in the literature [66].

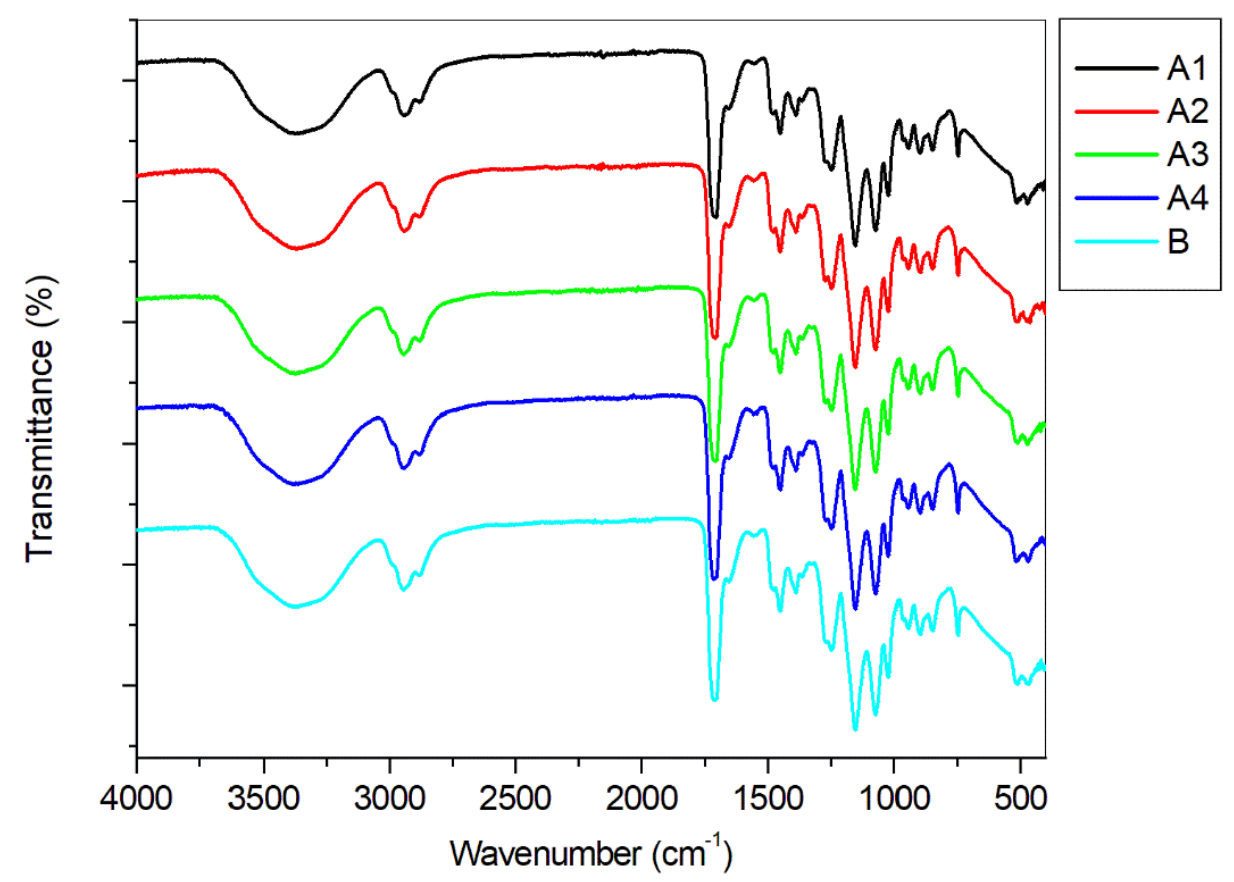

Figure 4. ATR-FTIR analysis of films A1-A4, B.

The optical characterization of every film was carried out by UV-vis absorption spectroscopy, taking advantage that the materials were transparent enough to make reliable direct measurements. Thus, placing the films in the optical path of the spectrophotometer yielded the spectra shown in Figure 5. Comparison of absorbance at $563 \mathrm{~nm}$ vs. RB concentration follows a linear relationship, suggesting no important aggregation inside the films. Moreover, the shape of the spectra remains invariant irrespective of the concentration tested. This statement must be taken cautiously since spectroscopically undetectable aggregates can lead to excitation energy trapping and hence, energy waste, as recently demonstrated with Phloxine B by San Román and co-workers [67]. The same group has recently described the behavior of RB in PHEMA films from a photophysical standpoint, at concentrations of photosensitizer one or two orders of magnitude higher than ours (ca. $1 \mathrm{mM}$ for film A4). These authors detected noticeable self-quenching effects above $10 \mathrm{mM}$ [68].

Despite the existence of some experimental uncertainty on the determination of film thickness, and considering a concentration of RB inside the matrix of ca. $1 \mathrm{mM}$ for A4, application of the Beer-Lambert law affords an extinction coefficient for this photosensitizer of ca. $10^{5} \mathrm{M}^{-1} \mathrm{~cm}^{-1}$ inside the film, in agreement with the value described in the literature (105,000 $\mathrm{M}^{-1} \mathrm{~cm}^{-1}$ for the monomeric form in water) [69].

Films were soaked in water for several months to test the potential leaching of the photosensitizer out of the polymeric matrix. After four months immersed in water no RB was detected in solution as measured by UV-vis absorption spectroscopy (see a picture of A4 in Figure 2c). Likely, the presence of the ATAC monomer is responsible for maintaining the photosensitizer electrostatically bound to the polymeric matrix. A film containing RB (835 nmol/g polymer) made with only HEMA:PEGDMA (90:10) was prepared to test this hypothesis and, as expected, partial leaching of the photosensitizer took place after hours of immersion in water (data not shown). 


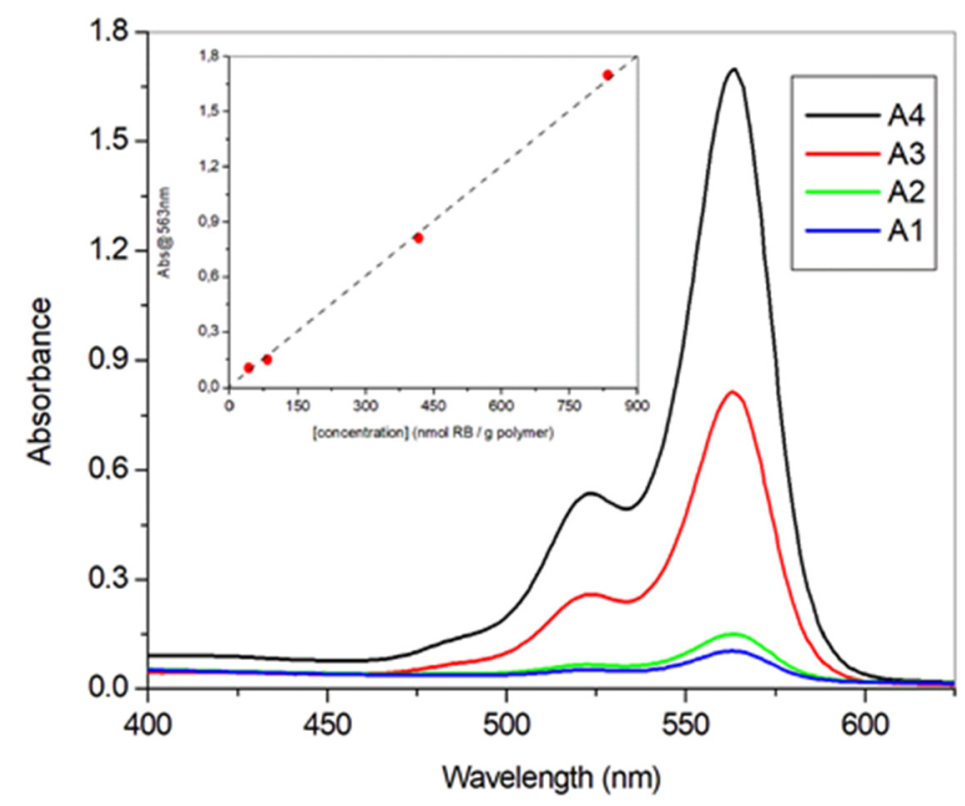

Figure 5. UV-vis absorption spectra of A1-A4 films. Inset: absorbance at $563 \mathrm{~nm}$ as a function of RB loading (linear fit with $\mathrm{R}=0.9995$, slope $=0.00203 \pm 0.00004$ ).

\subsection{Photochemical Generation of Singlet Oxygen by RB@PHEMA Films}

The ability of A1-A4 films to generate singlet oxygen upon irradiation was tested using the well-known probe of this species 9,10-dimethylanthracene (DMA). This is a chemical trap of ${ }^{1} \mathrm{O}_{2}$ frequently used to estimate the photoactivity of molecules and polymers. DMA absorption at $300-400 \mathrm{~nm}$ fades out upon reaction with ${ }^{1} \mathrm{O}_{2}$ due to the formation of the corresponding endoperoxide, not absorbing in such spectral region. In Figure $6 \mathrm{a}$ it is shown the fundamentals of photosensitized generation of ${ }^{1} \mathrm{O}_{2}$, in Figure $6 \mathrm{~b}$ the reaction of ${ }^{1} \mathrm{O}_{2}$ with DMA, in Figure $6 \mathrm{c}$ a representative example of monitorization of the reaction by UV-vis absorption spectroscopy and in Figure $6 \mathrm{~d}$ the fitting of the data of a selected replica to the pseudo-first order kinetic model to obtain the corresponding observed kinetic constant $\left(\mathrm{k}_{\mathrm{obs}}\right)$. Note that, since DMA oxygenation is carried out using a heterogeneous photosensitizer, a notable variability in the calculated $k_{o b s}$ is obtained, and for this reason all the measurements were done by triplicate. The averaged values can be used to estimate the relative photoactivity of each material (Table 1).

Irradiations of polymers A1-A4 in the presence of $10^{-4}$ M DMA in EtOH: $\mathrm{H}_{2} \mathrm{O}(1: 1$, $\mathrm{v}: \mathrm{v})$ were carried out using two white light lamps as energy sources (total irradiance $2 \times 180 \mathrm{~mW} / \mathrm{cm}^{2}$ ). The kinetic analysis of DMA absorption yielded constants in the range 184 to $270 \times 10^{-3} \mathrm{~min}^{-1}$. $\mathrm{K}_{\mathrm{obs}}$ values can be seen in Table 1 and Figure 7a. Self-sensitized oxidation of DMA, due to the residual absorption of this probe around $400 \mathrm{~nm}$, must be considered since it yields a measurable value of $k_{\text {obs }}$ (value for polymer $\mathbf{B}$ ). The trend followed by the values of $k_{o b s}$, as a function of $\mathbf{R B}$ concentration, is slightly ascending (significant statistical difference was found, $p \leq 0.01$, between control B and A1-A4 films, but no within the A1-A4 series). The curve is remarkably flat, which could be associated with several processes. One of the possibilities is that some degree of energy trapping would be taking place, even at such low concentrations of RB $[67,68]$. While this is out of the scope of the present study, further studies are required to clarify this hypothesis.

Another advantageous property of $\mathbf{A 4}$ film is its reusability in multiple cycles of oxygenation [70]. Thus, in a first cycle, $50 \mathrm{mg}$ of polymer $\mathbf{A} 4$ was irradiated in the presence of $3 \mathrm{~mL}$ of $10^{-4} \mathrm{M}$ DMA in EtOH: $\mathrm{H}_{2} \mathrm{O}(1: 1, \mathrm{v}: \mathrm{v})$ for $15 \mathrm{~min}$. Then, the film was introduced in a freshly prepared solution of $10^{-4} \mathrm{M}$ DMA in $\mathrm{EtOH}: \mathrm{H}_{2} \mathrm{O}(1: 1, \mathrm{v}: \mathrm{v})$ and irradiated again for $15 \mathrm{~min}$. This procedure was repeated up to 10 times (Figure $7 \mathrm{~b}$ ). After the tenth cycle, the colour of the material faded notably, but the polymer remained highly photoactive in terms of photooxygenation conversion (maintained at a constant value of ca. $90 \%$ ). The 
total light dose received by the film in each irradiation cycle is $324 \mathrm{~J} / \mathrm{cm}^{2}$, and after all the process, the total light dose received by the polymer is $3240 \mathrm{~J} / \mathrm{cm}^{2}$.

(a)

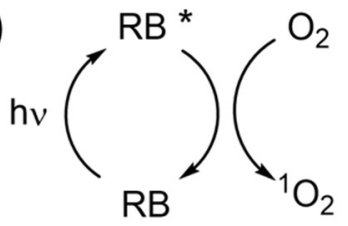

(c)

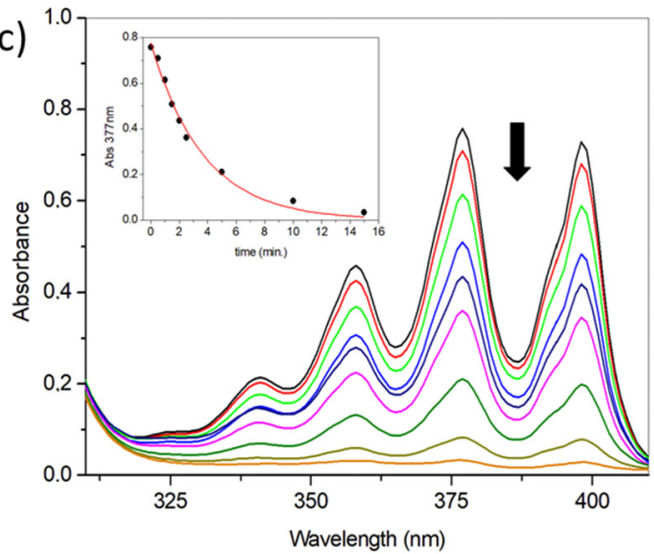

(b)

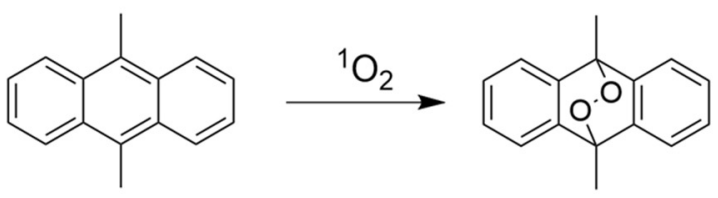

(d)

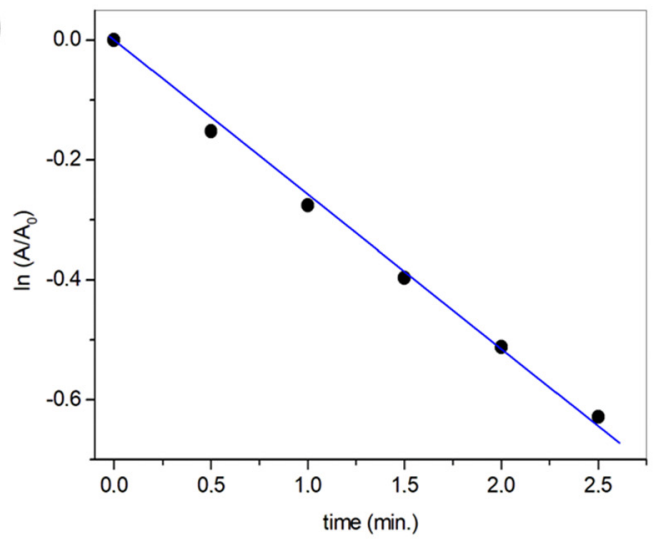

Figure 6. (a) Photosensitized generation of ${ }^{1} \mathrm{O}_{2}$ from irradiated $\mathbf{R B}$; (b) DMA reaction with ${ }^{1} \mathrm{O}_{2}$; (c) Illustrative example of DMA reactivity monitored by UV-vis absorption spectroscopy; (d) Illustrative fitting to a pseudo-first order kinetic model, using selected irradiation as an example. Note that to obtain the values shown in Table 1, the procedure was performed by triplicate and the values averaged.

(a)

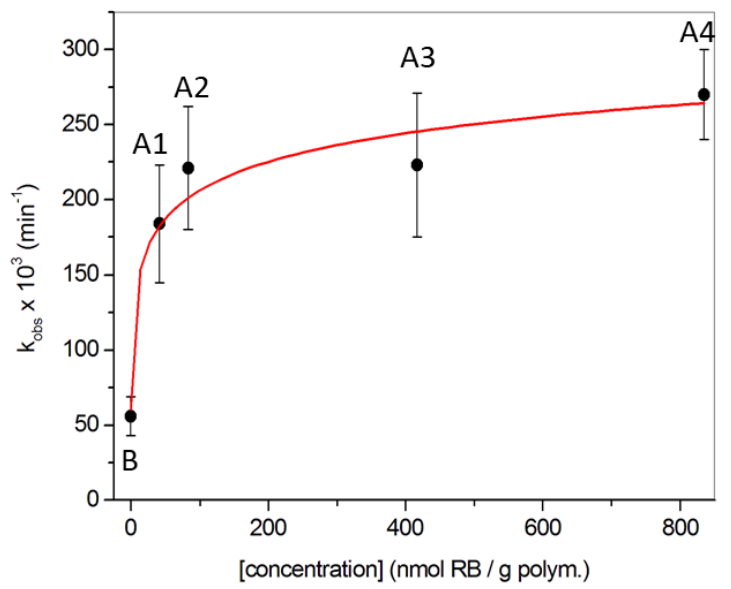

(b)

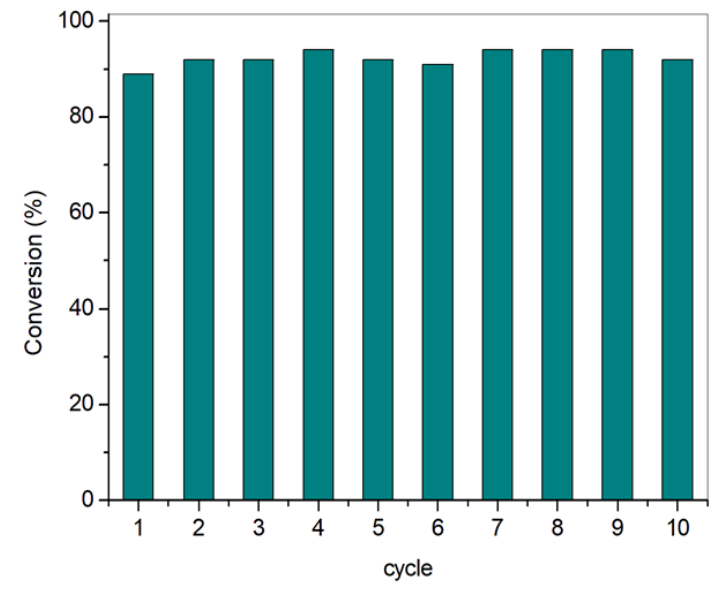

Figure 7. (a) Observed kinetic constants of the reaction between DMA and ${ }^{1} \mathrm{O}_{2}$ generated by irradiated polymers A1-A4, B; (b) Conversion yield of the reaction between DMA and ${ }^{1} \mathrm{O}_{2}$ generated by the same sample of irradiated polymer A4 (see text for details) during 10 cycles.

\subsection{Photodynamic Activity of RB@PHEMA Films against P. aeruginosa}

Planktonic suspensions of P. aeruginosa ATCC 27.853 (ca. $8 \log _{10} \mathrm{CFU} / \mathrm{mL}$ initial load) were exposed to irradiation in the presence of A4 film (fragments of $25 \mathrm{mg}$ ) with a source of white light for 5, 10, 15 and $30 \mathrm{~min}$ (light doses of 24, 48, 72 and $144 \mathrm{~J} / \mathrm{cm}^{2}$, respectively). As can be seen in Figure 8 , at a dose of $48 \mathrm{~J} / \mathrm{cm}^{2}$ the population reduction was statistically significant $\left(2 \log _{10} \mathrm{CFU} / \mathrm{mL}\right)$ and at $72 \mathrm{~J} / \mathrm{cm}^{2}$ the bacterial eradication was complete $\left(8 \log _{10} \mathrm{CFU} / \mathrm{mL}\right)$. Neither polymer $\mathbf{B}$ without $\mathbf{R B}$ nor irradiation without films yielded any reduction of the bacterial population. The eradication of P. aeruginosa 
using RB is very remarkable since it is well known that this pathogen is not appreciably inactivated by anionic RB in solution, although it is efficient for Gram-positive species [57]. The reason for this behavior can be ascribed to the fact that Gram-negative bacteria have a lipopolysaccharide (LPS) containing outer cell wall, making such bacteria much less susceptible to photosensitization [71]. Cationic photosensitizers (porphyrins, bodipys, etc) have been firmly established as good agents against this class of pathogens [71-74]. For this reason, the complete eradication of P. aeruginosa using an anionic photosensitizer like RB results notable. A similar effect has been described by the conjugation of noncationic photosensitizers with cationic peptides, acting as potentiating molecules of the photodynamic activity (disrupting the wall and then allowing a more efficient attack of $\left.{ }^{1} \mathrm{O}_{2}\right)$ [75].

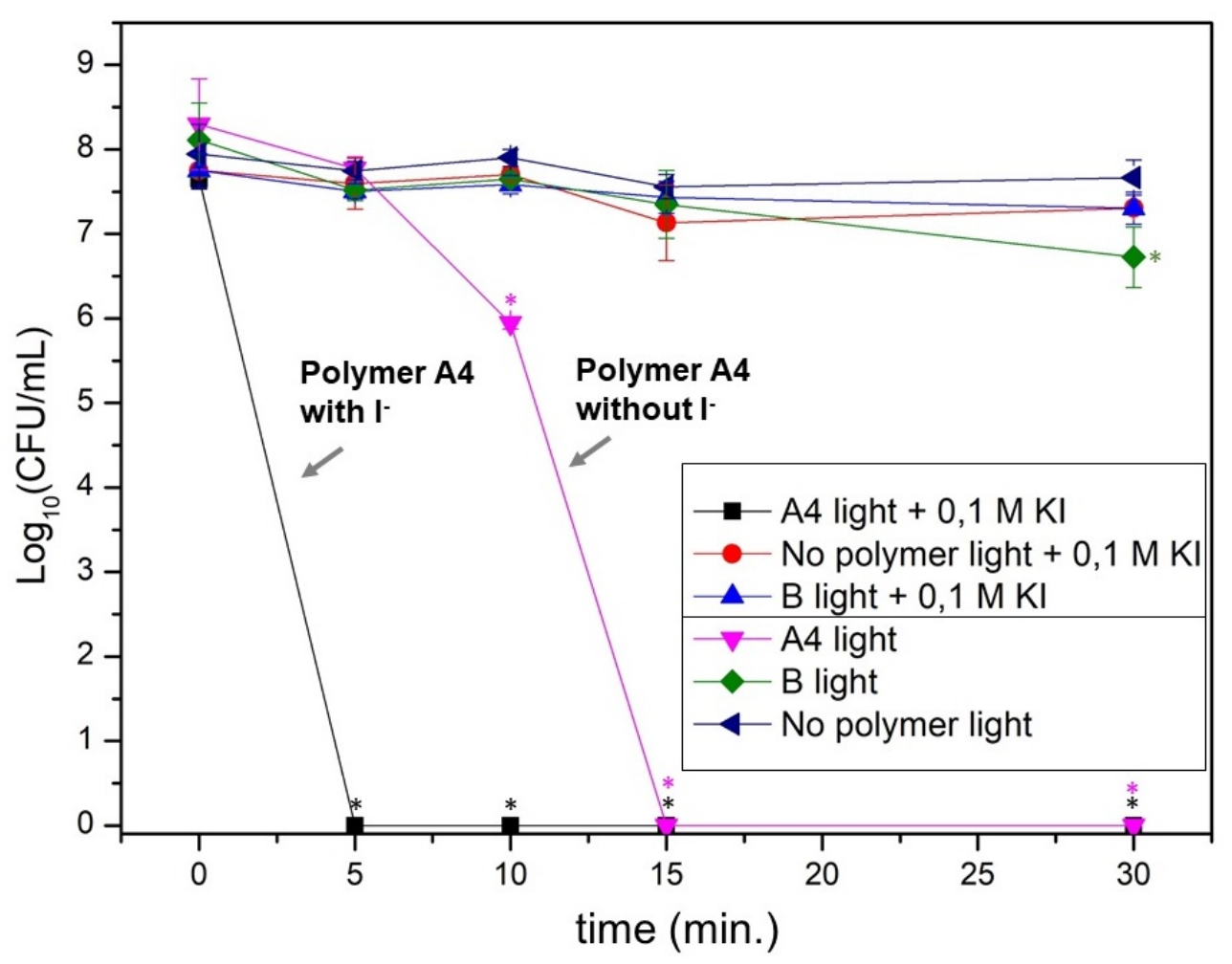

Figure 8. Photodynamic inactivation assays against $P$. aeruginosa with polymers A4 or B, with and without iodide anion and with or without light (see legend for details). Asterisks $\left(^{*}\right)$ indicate significant differences with respect to value at time $0 \mathrm{~min}$ for each aPDI condition $(p \leq 0.01)$.

The most remarkable aPDI effect was observed when irradiation of $P$. aeruginosa was carried out in the presence of potassium iodide $(100 \mathrm{mM})$. As can be seen in Figure 8 , the complete reduction of the bacterial population $\left(8 \log _{10} \mathrm{CFU} / \mathrm{mL}\right)$ occurs only with the minimum provided light dose of $24 \mathrm{~J} / \mathrm{cm}^{2}$ ( $5 \mathrm{~min}$. of irradiation) $(p \leq 0.01$ ). Although the effect of iodide for irradiation with photosensitizers in solution has already been described (see Introduction), there are only two reports of this effect when using material-supported photosensitizers (one in the case of polystyrene fibers made by electrospinning [54] and the other one using nanoparticles of the same material [63]). The assays presented in this study describe the utility of RB-loaded PHEMA polymeric films to eradicate P. aeruginosa by irradiation as well as the antimicrobial activity enhancement by the addition of iodide anion.

The corresponding controls in the dark were also carried out, yielding no killing of the pathogen (not shown). This observation implies that the presence of ammonium groups in the structure of the PHEMA films, introduced by the monomer ATAC, is not enough to 
impart a significant antimicrobial activity in the dark, as it has been described for other materials [5-13,76,77].

It has been reported that, in solution, killing activity enhancement caused by iodide anion is due to the generation of both (a) short-lived reactive iodine species and (b) stable and long-term acting microbiocidal species like iodine/triiodide $\left(\mathrm{I}_{2} / \mathrm{I}_{3}{ }^{-}\right)$. The prevalence of one or other species depends largely on the concentration of $\mathrm{I}^{-}$, being favoured the stable species by higher concentrations of it. Additionally, the group of Durantini has demonstrated enhanced intersystem crossing (ISC) to the first excited triplet state $\left(\mathrm{T}_{1}\right)$ of bodipy photosensitizers when iodide anion is present in the medium, which also could enhance the formation of $\mathrm{I}_{3}^{-}$(via oxidation of $\mathrm{I}^{-}$by ${ }^{1} \mathrm{O}_{2}$ ) [59]. The exact mechanism for the generation of all the aforementioned species is not fully understood and the reader is referred to the pertinent literature for more details [61].

Our interest was to determine the actual formation of $\mathrm{I}_{3}{ }^{-}$species since it is very easy to detect and follow due to their characteristic UV-vis absorption spectra, with peaks at $287 \mathrm{~nm}$ and $351 \mathrm{~nm}$ [54]. Thus, formation in solution was confirmed by irradiation of an aqueous solution of $100 \mathrm{mM} \mathrm{I}^{-}$in the presence of $\mathbf{R B} 5 \mu \mathrm{M}$ (Figure 9a). At $10 \mathrm{~min}$ of irradiation the formation of a band at $351 \mathrm{~nm}$ is a clear signature of $\mathrm{I}_{3}{ }^{-}$. In parallel to the rising of this band, there is progressive bleaching of the absorption of $\mathbf{R B}$ at $550 \mathrm{~nm}$. Further irradiation up to 48 min led to the intensification of the $\mathrm{I}_{3}{ }^{-}$band and complete bleaching of the RB absorption (illustrative picture in Figure 9b).

(a)

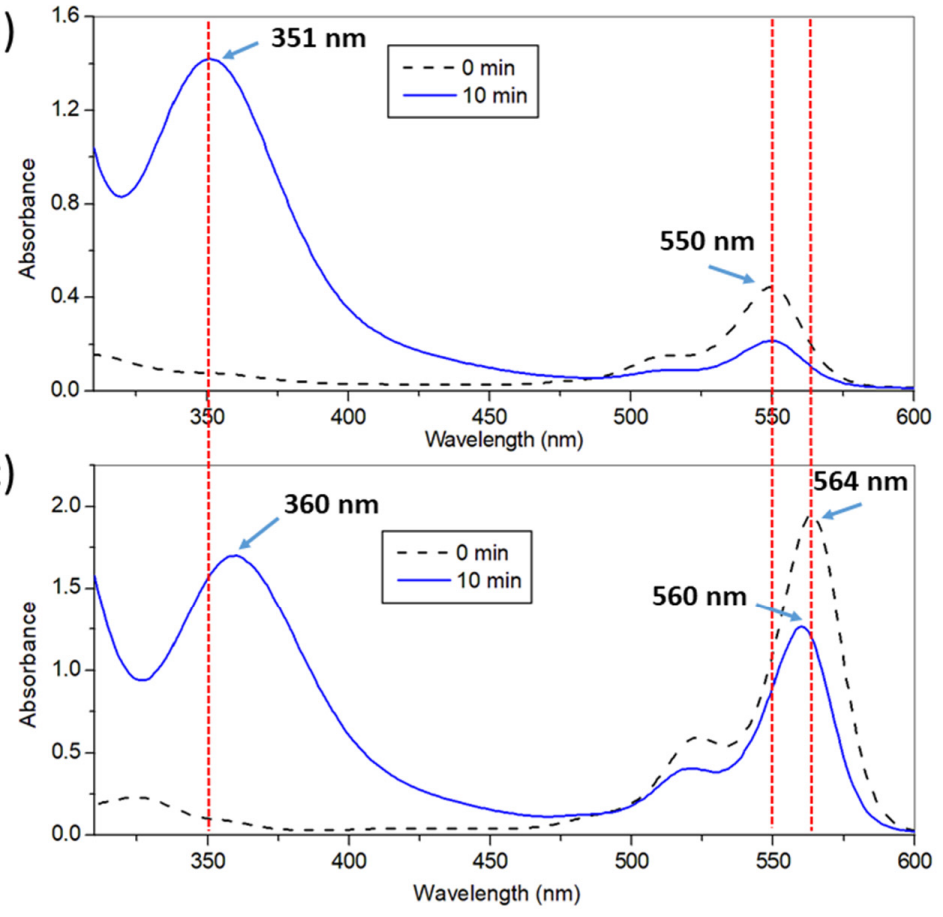

(b)

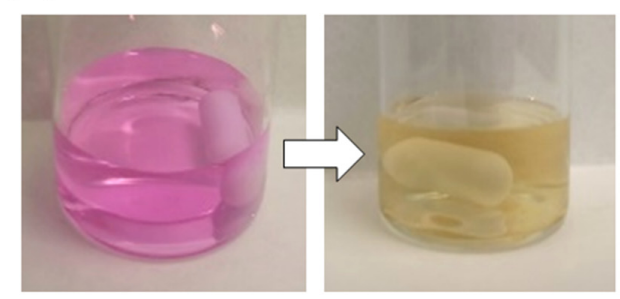

(d)

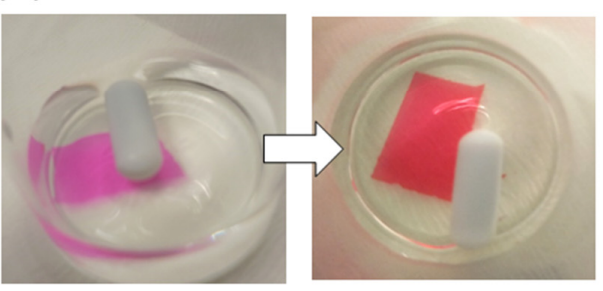

Figure 9. (a) UV-vis absorption spectra of a solution of RB $(5 \mu \mathrm{M})$ and $\mathrm{KI}(0.1 \mathrm{M})$ before (dashed line) and after irradiation for 10 min (continuous line); (b) Visual aspect of the solution indicated in (a) at time 0 and after 48 min of irradiation; (c) UV-vis absorption spectra of an A4 film immersed in KI solution $(0.1 \mathrm{M})$ before (dashed line) and after irradiation for 10 min (continuous line); (d) Visual aspect of the solution and polymer indicated in (c) at time 0 and after 35 min of irradiation.

The same procedure was carried out using polymer $\mathbf{A} 4$ as a source of ${ }^{1} \mathrm{O}_{2}$ and interesting changes were noticed. First, $\mathrm{I}_{3}{ }^{-}$formation was detected spectroscopically after $10 \mathrm{~min}$ of irradiation (Figure 9c) and by the naked eye after $35 \mathrm{~min}$ of irradiation (Figure 9d). The generated triiodide is entrapped electrostatically inside the film as evidenced by the fact that its absorption occurs shifted to $360 \mathrm{~nm}$ and by the colour change in the film (from pink to red). Considering the absorbance of the new band in the film, the extinction coefficient of $\mathrm{I}_{3}{ }^{-}\left(2 \cdot 2 \cdot 10^{4} \mathrm{M}^{-1} \mathrm{~cm}^{-1}\right)[78]$ and the thickness of the films, a rough calculation can estimate 
the concentration of this species inside the films at ca. $0.8 \mathrm{M}$. Such a high concentration of $\mathrm{I}_{3}{ }^{-}$makes the irradiated polymers as truly permanent antibacterial materials. To check this hypothesis, the following assay was carried out: an A4 film was irradiated in the presence of $\mathrm{I}^{-}$for $15 \mathrm{~min}$. and afterward the solution was spiked with P. aeruginosa $\left(8 \log _{10} \mathrm{CFU} / \mathrm{mL}\right)$. After 5 min of incubation in the dark, the bacterial killing was complete (data not shown). This long-term use, once finished the irradiation time, is coincident with the behaviour shown for photoactive polystyrene fibers $[54,63]$.

Second, the irradiation of the film induced a small blue shift in the absorption of encapsulated RB, from $564 \mathrm{~nm}$ to $560 \mathrm{~nm}$, probably indicating a change in the surrounding environment. Additionally, extended irradiation of the film up to 35 min yielded no additional bleaching of $\mathrm{RB}$ absorption (this is the reason why the film remains coloured in Figure 9d). All in all, the use of $\mathrm{I}^{-}$in conjunction with entrapment of RB in the PHEMA matrix seems to provide a protective environment for the photosensitizer, hindering its complete photodegradation.

\section{Conclusions}

In summary, the non-covalent RB encapsulation in a series of PHEMA hydrogel films has led to photoactive materials generating ${ }^{1} \mathrm{O}_{2}$, as demonstrated by the reactivity shown towards DMA. Polymer A4, with the highest RB load, possesses photobactericidal properties since it can eradicate a Gram-negative P. aeruginosa (planktonic state) population of $8 \log _{10} \mathrm{CFU} / \mathrm{mL}$ at a total light dose of $72 \mathrm{~J} / \mathrm{cm}^{2}$ (15 min. of white light exposure). Notably, this photodynamic action is highly enhanced by the addition of potassium iodide $100 \mathrm{mM}$, reducing the total light dose needed to $24 \mathrm{~J} / \mathrm{cm}^{2}$ ( $5 \mathrm{~min}$. irradiation time). The generation of bactericidal $\mathrm{I}_{3}{ }^{-}$is demonstrated by the $\mathrm{UV}$-absorption signature of this species. The photogenerated $\mathrm{I}_{3}{ }^{-}$becomes trapped in the PHEMA matrix, at a high concentration (almost ca. $1 \mathrm{M}$ ), imparting to the polymer a long-lasting ability to kill bacteria.

Supplementary Materials: The following are available online at https:/ /www.mdpi.com/article/ 10.3390/polym13142227/s1, Figure S1: Experimental setup for the irradiations of polymers in the presence of singlet oxygen trap DMA, Figure S2: Experimental setup for the irradiations of polymers in the presence of bacteria.

Author Contributions: Investigation A.M.L.-F., I.M.R., R.d.L. and F.G.; conceptualization, F.G.; writing-original draft preparation, F.G.; Writing—Review and Editing, F.G., R.d.L. and I.M.R.; supervision, F.G. and R.d.L.; project administration, F.G.; funding acquisition, F.G. and R.d.L. All authors have read and agreed to the published version of the manuscript.

Funding: IMR acknowledges the financial support from Generalitat Valenciana (Santiago Grisolía fellowship GRISOLIAP/2018/071). RdL. was funded through a Beatriz Galindo Fellowship of the Ministerio de Educación y Formación Profesional, Spanish Government (BGP18/00062).

Acknowledgments: The authors acknowledge the technical support provided by Servei Central d'Instrumentació Científica (SCIC) of Universitat Jaume I.

Conflicts of Interest: The authors declare no conflict of interest.

\section{References}

1. Cohen, M.L. Changing patterns of infectious diseases. Nature 2000, 406, 762-767. [CrossRef]

2. Nadimpalli, M.L.; Chan, C.W.; Doron, S. Antibiotic resistance: A call to action to prevent the next epidemic of inequality. Nat. Med. 2021, 27, 186-187. [CrossRef]

3. Al-Tawfiq, J.A.; Tambyah, P.A. Healthcare associated infections (HAI) perspectives. J. Infect. Public Health 2014, 7, 339-344. [CrossRef] [PubMed]

4. Shi, Q.; Huang, C.; Xiao, T.; Wu, Z.; Xiao, Y. A retrospective analysis of Pseudomonas aeruginosa bloodstream infections: Prevalence, risk factors, and outcome in carbapenem-susceptible and -non-susceptible infections. Antimicrob. Resist. Infect. Control. 2019, 8, 1-9. [CrossRef] [PubMed]

5. Kenawy, E.R.; Worley, S.D.; Broughton, R. The chemistry and applications of antimicrobial polymers: A state-of-the-art review. Biomacromolecules 2007, 8, 1359-1384. [CrossRef] [PubMed] 
6. Nigmatullin, R.; Gao, F. Onium-functionalised polymers in the design of non-leaching antimicrobial surfaces. Macromol. Mater. Eng. 2012, 297, 1038-1074. [CrossRef]

7. Muñoz-Bonilla, A.; Fernández-García, M. The roadmap of antimicrobial polymeric materials in macromolecular nanotechnology. Eur. Polym. J. 2015, 65, 46-62. [CrossRef]

8. Jiao, Y.; Niu, L.; Ma, S.; Li, J.; Tay, F.R.; Chen, J. Quaternary ammonium-based biomedical materials: State-of-the-art, toxicological aspects and antimicrobial resistance. Prog. Polym. Sci. 2017, 71, 53-90. [CrossRef]

9. Ding, X.; Duan, S.; Ding, X.; Liu, R.; Xu, F.J. Versatile Antibacterial Materials: An Emerging Arsenal for Combatting Bacterial Pathogens. Adv. Funct. Mater. 2018, 28, 1-19. [CrossRef]

10. Wei, T.; Yu, Q.; Chen, H. Responsive and Synergistic Antibacterial Coatings: Fighting against Bacteria in a Smart and Effective Way. Adv. Healthc. Mater. 2019, 8, 1-24. [CrossRef]

11. Luo, H.; Yin, X.Q.; Tan, P.F.; Gu, Z.P.; Liu, Z.M.; Tan, L. Polymeric antibacterial materials: Design, platforms and applications. J. Mater. Chem. B 2021, 9, 2802-2815. [CrossRef] [PubMed]

12. Koufakis, E.; Manouras, T.; Anastasiadis, S.H.; Vamvakaki, M. Film Properties and Antimicrobial Efficacy of Quaternized PDMAEMA Brushes: Short vs. Long Alkyl Chain Length. Langmuir 2020, 36, 3482-3493. [CrossRef] [PubMed]

13. Díez-Pascual, A.M. Recent progress in antimicrobial nanomaterials. Nanomaterials 2020, 10, 2315. [CrossRef]

14. Valdés, A.; Ramos, M.; Beltrán, A.; Jiménez, A.; Garrigós, M.C. State of the art of antimicrobial edible coatings for food packaging applications. Coatings 2017, 7, 56. [CrossRef]

15. Wainwright, M. Photodynamic Antimicrobial Chemotherapy. J. Antimicrob. Chemother. 1998, 42, 13-28. [CrossRef]

16. Hamblin, M.R.; Hasan, T. Photodynamic therapy: A new antimicrobial approach to infectious disease? Photochem. Photobiol. 2004, 3, 436-450. [CrossRef]

17. Maisch, T. Strategies to optimize photosensitizers for photodynamic inactivation of bacteria. J. Photochem. Photobiol. B Biol. 2015, 150, 2-10. [CrossRef]

18. Hamblin, M.R. Antimicrobial photodynamic inactivation: A bright new technique to kill resistant microbes. Curr. Opin. Microbiol. 2016, 33, 67-73. [CrossRef]

19. Wainwright, M.; Maisch, T.; Nonell, S.; Plaetzer, K.; Almeida, A.; Tegos, G.P.; Hamblin, M.R. Photoantimicrobials—Are we afraid of the light? Lancet Infect. Dis. 2017, 17, e49-e55. [CrossRef]

20. Cieplik, F.; Deng, D.; Crielaard, W.; Buchalla, W.; Hellwig, E.; Al-Ahmad, A.; Maisch, T. Antimicrobial photodynamic therapyWhat we know and what we don't. Crit. Rev. Microbiol. 2018, 44, 571-589. [CrossRef] [PubMed]

21. Hamblin, M.R.; Abrahamse, H. Can light-based approaches overcome antimicrobial resistance? Drug Dev. Res. 2019, 80, 48-67. [CrossRef] [PubMed]

22. Nakonieczna, J.; Wozniak, A.; Pieranski, M.; Rapacka-Zdonczyk, A.; Ogonowska, P.; Grinholc, M. Photoinactivation of ESKAPE pathogens: Overview of novel therapeutic strategy. Future Med. Chem. 2019, 11, 443-461. [CrossRef] [PubMed]

23. Jia, Q.; Song, Q.; Li, P.; Huang, W. Rejuvenated Photodynamic Therapy for Bacterial Infections. Adv. Healthc. Mater. 2019, 1900608, 1-19. [CrossRef]

24. Decraene, V.; Pratten, J.; Wilson, M. Cellulose acetate containing toluidine blue and rose bengal is an effective antimicrobial coating when exposed to white light. Appl. Environ. Microbiol. 2006, 72, 4436-4439. [CrossRef]

25. Noimark, S.; Dunnill, C.W.; Wilson, M.; Parkin, I.P. The role of surfaces in catheter-associated infections. Chem. Soc. Rev. 2009, 38, 3435-3448. [CrossRef]

26. Spagnul, C.; Turner, L.C.; Boyle, R.W. Immobilized photosensitizers for antimicrobial applications. J. Photochem. Photobiol. B Biol. 2015, 150, 11-30. [CrossRef]

27. Mesquita, M.Q.; Dias, C.J.; Neves, M.G.P.M.S.; Almeida, A.; Faustino, M.A.F. Revisiting current photoactive materials for antimicrobial photodynamic therapy. Molecules 2018, 23, 2424. [CrossRef] [PubMed]

28. Henke, P.; Lang, K.; Kubát, P.; Sýkora, J.; Šlouf, M.; Mosinger, J. Polystyrene nanofiber materials modified with an externally bound porphyrin photosensitizer. ACS Appl. Mater. Interfaces 2013, 5, 3776-3783. [CrossRef]

29. Martínez, S.R.; Palacios, Y.B.; Heredia, D.A.; Aiassa, V.; Bartolilla, A.; Durantini, A.M. Self-Sterilizing 3D-Printed Polylactic Acid Surfaces Coated with a BODIPY Photosensitizer. ACS Appl. Mater. Interfaces 2021, 13, 11597-11608. [CrossRef]

30. Peddinti, B.S.T.; Scholle, F.; Ghiladi, R.A.; Spontak, R.J. Photodynamic Polymers as Comprehensive Anti-Infective Materials: Staying Ahead of a Growing Global Threat. ACS Appl. Mater. Interfaces 2018, 10, 25955-25959. [CrossRef] [PubMed]

31. Mesquita, M.Q.; Menezes, J.C.J.M.D.S.; Pires, S.M.G.; Neves, M.G.P.M.S.; Simões, M.M.Q.; Tomé, A.C.; Cavaleiro, J.A.S.; Cunha, Â.; Daniel-Da-Silva, A.L.; Almeida, A.; et al. Pyrrolidine-fused chlorin photosensitizer immobilized on solid supports for the photoinactivation of Gram negative bacteria. Dye. Pigment. 2014, 110, 123-133. [CrossRef]

32. Wylie, M.P.; Irwin, N.J.; Howard, D.; Heydon, K.; McCoy, C.P. Hot-melt extrusion of photodynamic antimicrobial polymers for prevention of microbial contamination. J. Photochem. Photobiol. B Biol. 2021, 214, 112098. [CrossRef] [PubMed]

33. Ferrari, G.V.; Andrada, M.E.; Natera, J.; Muñoz, V.A.; Paulina Montãna, M.; Gambetta, C.; Boiero, M.L.; Montenegro, M.A.; Massad, W.A.; García, N.A. The employment of a removable chitosan-derivatized polymeric sensitizer in the photooxidation of polyhydroxylated water-pollutants. Photochem. Photobiol. 2014, 90, 1251-1256. [CrossRef]

34. Aluigi, A.; Sotgiu, G.; Torreggiani, A.; Guerrini, A.; Orlandi, V.T.; Corticelli, F.; Varchi, G. Methylene Blue Doped Films of Wool Keratin with Antimicrobial Photodynamic Activity. ACS Appl. Mater. Interfaces 2015, 7, 17416-17424. [CrossRef] [PubMed] 
35. Carpenter, B.L.; Scholle, F.; Sadeghifar, H.; Francis, A.J.; Boltersdorf, J.; Weare, W.W.; Argyropoulos, D.S.; Maggard, P.A.; Ghiladi, R.A. Synthesis, Characterization, and Antimicrobial Efficacy of Photomicrobicidal Cellulose Paper. Biomacromolecules 2015, 16, 2482-2492. [CrossRef]

36. Stoll, K.R.; Scholle, F.; Zhu, J.; Zhang, X.; Ghiladi, R.A. BODIPY-embedded electrospun materials in antimicrobial photodynamic inactivation. Photochem. Photobiol. Sci. 2019, 18, 1923-1932. [CrossRef]

37. Varela-Garcia, A.; Gomez-Amoza, J.L.; Concheiro, A.; Alvarez-Lorenzo, C. Imprinted contact lenses for ocular administration of antiviral drugs. Polymers 2020, 12, 2026. [CrossRef] [PubMed]

38. Laurenti, M.; Grochowicz, M.; Cauda, V. Porous ZnO/2-hydroxyethyl methacrylate eluting coatings for ureteral stent applications. Coatings 2018, 8, 376. [CrossRef]

39. Wang, C.; Rubakhin, S.S.; Enright, M.J.; Sweedler, J.V.; Nuzzo, R.G. 3D Particle-Free Printing of Biocompatible Conductive Hydrogel Platforms for Neuron Growth and Electrophysiological Recording. Adv. Funct. Mater. 2021, 31, 1-10. [CrossRef]

40. Tian, Y.; Shumway, B.R.; Meldrum, D.R. A new cross-linkable oxygen sensor covalently bonded into poly(2-hydroxyethyl methacrylate)-co-polyacrylamide thin film for dissolved oxygen sensing. Chem. Mater. 2010, 22, 2069-2078. [CrossRef] [PubMed]

41. Chen, W.; Wang, Q.; Chen, J.; Zhang, Q.; Zhao, X.; Qian, Y.; Zhu, C.; Yang, L.; Zhao, Y.; Kong, X.Y.; et al. Improved Ion Transport and High Energy Conversion through Hydrogel Membrane with 3D Interconnected Nanopores. Nano Lett. 2020, 20, 5705-5713. [CrossRef] [PubMed]

42. Lin, Y.H.; Subramani, R.; Huang, Y.T.; Lee, Y.L.; Jan, J.S.; Chiu, C.C.; Hou, S.S.; Teng, H. Highly stable interface formation in onsite coagulation dual-salt gel electrolyte for lithium-metal batteries. J. Mater. Chem. A 2021, 9, 5675-5684. [CrossRef]

43. Horn, C.; Pospiech, D.; Allertz, P.J.; Müller, M.; Salchert, K.; Hommel, R. Chemical Design of Hydrogels with Immobilized Laccase for the Reduction of Persistent Trace Compounds in Wastewater. ACS Appl. Polym. Mater. 2021, 3, 2823-2834. [CrossRef]

44. Galindo, F.; Lima, J.C.; Luis, S.V.; Parola, A.J.; Pina, F. Write-read-erase molecular-switching system trapped in a polymer hydrogel matrix. Adv. Funct. Mater. 2005, 15, 541-545. [CrossRef]

45. Galindo, F.; Lima, J.C.; Luis, S.V.; Melo, M.J.; Jorge Parola, A.; Pina, F. Water/humidity and ammonia sensor, based on a polymer hydrogel matrix containing a fluorescent flavylium compound. J. Mater. Chem. 2005, 15, 2840-2847. [CrossRef]

46. Bru, M.; Burguete, M.I.; Galindo, F.; Luis, S.V.; Marín, M.J.; Vigara, L. Cross-linked poly(2-hydroxyethylmethacrylate) films doped with 1,2-diaminoanthraquinone (DAQ) as efficient materials for the colorimetric sensing of nitric oxide and nitrite anion. Tetrahedron Lett. 2006, 47, 1787-1791. [CrossRef]

47. Burguete, M.I.; Fabregat, V.; Galindo, F.; Izquierdo, M.A.; Luis, S.V. Improved polyHEMA-DAQ films for the optical analysis of nitrite. Eur. Polym. J. 2009, 45, 1516-1523. [CrossRef]

48. Fabregat, V.; Izquierdo, M.A.; Burguete, M.I.; Galindo, F.; Luis, S.V. Quantum dot-polymethacrylate composites for the analysis of NO $x$ by fluorescence spectroscopy. Inorg. Chim. Acta 2012, 381, 212-217. [CrossRef]

49. Fabregat, V.; Izquierdo, M.Á.; Burguete, M.I.; Galindo, F.; Luis, S.V. Nitric oxide sensitive fluorescent polymeric hydrogels showing negligible interference by dehydroascorbic acid. Eur. Polym. J. 2014, 55, 108-113. [CrossRef]

50. Fabregat, V.; Burguete, M.I.; Galindo, F.; Luis, S.V. Influence of polymer composition on the sensitivity towards nitrite and nitric oxide of colorimetric disposable test strips. Environ. Sci. Pollut. Res. 2017, 24, 3448-3455. [CrossRef]

51. López-López, N.; Muñoz Resta, I.; De Llanos, R.; Miravet, J.F.; Mikhaylov, M.; Sokolov, M.N.; Ballesta, S.; García-Luque, I.; Galindo, F. Photodynamic Inactivation of Staphylococcus aureus Biofilms Using a Hexanuclear Molybdenum Complex Embedded in Transparent polyHEMA Hydrogels. ACS Biomater. Sci. Eng. 2020, 6, 6995-7003. [CrossRef] [PubMed]

52. McCoy, C.P.; Craig, R.A.; McGlinchey, S.M.; Carson, L.; Jones, D.S.; Gorman, S.P. Surface localisation of photosensitisers on intraocular lens biomaterials for prevention of infectious endophthalmitis and retinal protection. Biomaterials 2012, 33, 7952-7958. [CrossRef]

53. Castro, K.A.D.F.; Moura, N.M.M.; Simões, M.M.Q.; Cavaleiro, J.A.S.; Faustino, M.d.A.F.; Cunha, Â.; Almeida Paz, F.A.; Mendes, R.F.; Almeida, A.; Freire, C.S.R.; et al. Synthesis and characterization of photoactive porphyrin and poly(2-hydroxyethyl methacrylate) based materials with bactericidal properties. Appl. Mater. Today 2019, 16, 332-341. [CrossRef]

54. Plíštil, L.; Henke, P.; Kubát, P.; Mosinger, J. Anion exchange nanofiber materials activated by daylight with a dual antibacterial effect. Photochem. Photobiol. Sci. 2014, 13, 1321-1329. [CrossRef] [PubMed]

55. Vecchio, D.; Gupta, A.; Huang, L.; Landi, G.; Avci, P.; Rodas, A.; Hamblina, M.R. Bacterial photodynamic inactivation mediated by methylene blue and red light is enhanced by synergistic effect of potassium iodide. Antimicrob. Agents Chemother. 2015, 59, 5203-5212. [CrossRef]

56. Agazzi, M.L.; Durantini, J.E.; Quiroga, E.D.; Alvarez, M.G.; Durantini, E.N. A novel tricationic fullerene C60 as broad-spectrum antimicrobial photosensitizer: Mechanisms of action and potentiation with potassium iodide. Photochem. Photobiol. Sci. 2021, 20, 327-341. [CrossRef]

57. Wen, X.; Zhang, X.; Szewczyk, G.; El-Hussein, A.; Huang, Y.-Y.; Sarna, T.; Hamblin, M.R. Potassium Iodide Potentiates Antimicrobial Photodynamic Inactivation Mediated by Rose Bengal in In Vitro and In Vivo Studies. Antimicrob. Agents Chemother. 2017, 61, 1-15. [CrossRef]

58. Huang, L.; Szewczyk, G.; Sarna, T.; Hamblin, M.R. Potassium Iodide Potentiates Broad-Spectrum Antimicrobial Photodynamic Inactivation Using Photofrin. ACS Infect. Dis. 2017, 3, 320-328. [CrossRef] 
59. Reynoso, E.; Quiroga, E.D.; Agazzi, M.L.; Ballatore, M.B.; Bertolotti, S.G.; Durantini, E.N. Photodynamic inactivation of microorganisms sensitized by cationic BODIPY derivatives potentiated by potassium iodide. Photochem. Photobiol. Sci. 2017, 16, 1524-1536. [CrossRef] [PubMed]

60. Vieira, C.; Gomes, A.T.P.C.; Mesquita, M.Q.; Moura, N.M.M.; Neves, G.P.M.S.; Faustino, A.F.; Almeida, A. An insight into the potentiation effect of potassium iodide on APDT efficacy. Front. Microbiol. 2018, 9, 1-16. [CrossRef] [PubMed]

61. Hamblin, M.R.; Abrahamse, H. Inorganic salts and antimicrobial photodynamic therapy: Mechanistic conundrums? Molecules 2018, 23, 3190. [CrossRef] [PubMed]

62. Huang, L.; El-Hussein, A.; Xuan, W.; Hamblin, M.R. Potentiation by potassium iodide reveals that the anionic porphyrin TPPS4 is a surprisingly effective photosensitizer for antimicrobial photodynamic inactivation. J. Photochem. Photobiol. B Biol. 2018, 178, 277-286. [CrossRef] [PubMed]

63. Kubát, P.; Henke, P.; Mosinger, J. The effect of iodide and temperature on enhancing antibacterial properties of nanoparticles with an encapsulated photosensitizer. Colloids Surf. B Biointerfaces 2019, 176, 334-340. [CrossRef] [PubMed]

64. Castro, K.A.D.F.; Brancini, G.T.P.; Costa, L.D.; Biazzotto, J.C.; Faustino, M.A.F.; Tomé, A.C.; Neves, M.G.P.M.S.; Almeida, A.; Hamblin, M.R.; Da Silva, R.S.; et al. Efficient photodynamic inactivation of Candida albicans by porphyrin and potassium iodide co-encapsulation in micelles. Photochem. Photobiol. Sci. 2020, 19, 1063-1071. [CrossRef]

65. Park, D.; Keszler, B.; Galiatsatos, V.; Kennedy, J.P. Amphiphilic networks. XI. Mechanical properties and morphology. J. Appl. Polym. Sci. 1997, 66, 901-910. [CrossRef]

66. Muñoz-Bonilla, A.; Zagora, J.; Plachá, D.; Echeverría, C.; Chiloeches, A.; Fernández-García, M. Chemical hydrogels bearing thiazolium groups with a broad spectrum of antimicrobial behavior. Polymers 2020, 12, 2853. [CrossRef]

67. Litman, Y.; Rodríguez, H.B.; San Román, E. Tuning the concentration of dye loaded polymer films for maximum photosensitization efficiency: Phloxine B in poly(2-hydroxyethyl methacrylate). Photochem. Photobiol. Sci. 2016, 15, 80-85. [CrossRef]

68. Ezquerra Riega, S.D.; Rodríguez, H.B.; Román, E.S. Rose bengal in poly(2-hydroxyethyl methacrylate) thin films: Selfquenching by photoactive energy traps. Methods Appl. Fluoresc. 2017, 5, 14010. [CrossRef]

69. Mirenda, M.; Dicelio, L.E.; Román, E.S. Effect of molecular interactions on the photophysics of Rose Bengal in polyelectrolyte solutions and self-assembled thin films. J. Phys. Chem. B 2008, 112, 12201-12207. [CrossRef]

70. Lacombe, S.; Pigot, T. Materials for selective photo-oxygenation vs. photocatalysis: Preparation, properties and applications in environmental and health fields. Catal. Sci. Technol. 2016, 6, 1571-1592. [CrossRef]

71. Pereira, M.A.; Faustino, M.A.F.; Tomé, J.P.C.; Neves, M.G.P.M.S.; Tomé, A.C.; Cavaleiro, J.A.S.; Cunha, Â.; Almeida, A. Influence of external bacterial structures on the efficiency of photodynamic inactivation by a cationic porphyrin. Photochem. Photobiol. Sci. 2014, 13, 680-690. [CrossRef] [PubMed]

72. Merchat, M.; Bertolini, G.; Giacomini, P.; Villanueva, A.; Jori, G. Meso-substituted cationic porphyrins as efficient photosensitizers of gram-positive and gram-negative bacteria. J. Photochem. Photobiol. B Biol. 1996, 32, 153-157. [CrossRef]

73. Minnock, A.; Vernon, D.I.; Schofield, J.; Griffiths, J.; Parish, J.H.; Brown, S.B. Photoinactivation of bacteria. Use of a cationic water-soluble zinc phthalocyanine to photoinactivate both gram-negative and gram-positive bacteria. J. Photochem. Photobiol. B Biol. 1996, 32, 159-164. [CrossRef]

74. Ragàs, X.; Sánchez-García, D.; Ruiz-González, R.; Dai, T.; Agut, M.; Hamblin, M.R.; Nonell, S. Cationic porphycenes as potential photosensitizers for antimicrobial photodynamic therapy. J. Med. Chem. 2010, 53, 7796-7803. [CrossRef] [PubMed]

75. Soukos, N.S.; Ximenez-Fyvie, L.A.; Hamblin, M.R.; Socransky, S.S.; Hasan, T. Targeted Antimicrobial Photochemotherapy. Antimicrob. Agents Chemother. 1998, 42, 2595-2601. [CrossRef]

76. Gavara, R.; de Llanos, R.; Pérez-Laguna, V.; Arnau del Valle, C.; Miravet, J.F.; Rezusta, A.; Galindo, F. Broad-Spectrum PhotoAntimicrobial Polymers Based on Cationic Polystyrene and Rose Bengal. Front. Med. 2021, 8, 1-10. [CrossRef]

77. del Valle, C.A.; Pérez-Laguna, V.; Resta, I.M.; Gavara, R.; Felip-León, C.; Miravet, J.F.; Rezusta, A.; Galindo, F. A cost-effective combination of Rose Bengal and off-the-shelf cationic polystyrene for the photodynamic inactivation of Pseudomonas aeruginosa. Mater. Sci. Eng. C 2020, 117, 111302. [CrossRef]

78. Morrison, M.; Bayse, G.S.; Michaels, A.W. Determination of spectral properties of aqueous I2 and I3- and the equilibrium constant. Anal. Biochem. 1971, 42, 195-201. [CrossRef] 